\title{
The Meanings of Re-Socialization to Correctional Officers in a Women's Prison: Between Care and Control
}

\author{
Mariana Barcinski ${ }^{1}$ \\ Sabrina Daiana Cúnico \\ Marina Valentim Brasil \\ Pontifícia Universidade Católica do Rio Grande do Sul, Porto Alegre, RS, Brazil
}

\begin{abstract}
The present study aimed at investigating a correctional officer's perception of her duties, specially with regard to her role as co-participant in the processes of re-socialisation of women inmates. Through the Critical Discourse Analysis of a semi-structured interview, one identified contradictory meanings attributed to this officer, regarding the process of re-socialisation. By clarifying the details of her daily routine, the meanings of re-socialisation and the responsibility towards the re-socialising process were being built by the interviewee during her discourse. Such responsibility was at times understood as inherent to the job of an officer, at other was identified as being exclusively the prisoners. Despite being made with a simplistic remark, a third aspect was considered by the officer as determinant of the possibilities of the female' re-socialisation: the social issue and the economic context from where these women come. Although this criticism had not been fully developed, one understands that the failure or the difficulties inherent to the re-socialising process should also be credited to a social structure which hinders the real possibilities of social re-integration. Therefore, re-socialising would be simultaneously the result of personal effort (both the inmates' and the officers') and of a fairer and more equal social arrangement.
\end{abstract}

Keywords: Re-socialization, women's prison, correctional officers.

\section{Significados da Ressocialização para Agentes Penitenciárias em uma Prisão Feminina: Entre o Cuidado e o Controle}

\section{Resumo}

O presente estudo objetivou investigar a percepção de uma agente penitenciária acerca de suas atribuições, especialmente sobre o seu papel como co-participante em processos de ressocialização de mulheres privadas de liberdade. Através da Análise Crítica do Discurso de uma entrevista semiestruturada, identificou-se significados contraditórios atribuídos por esta agente ao processo de ressocialização. Ao explicitar as especificidades do seu dia-a-dia de trabalho, os sentidos da ressocialização e a responsabilidade frente ao processo ressocializador foram construídos discursivamente pela entrevistada. Tal responsabilidade foi por vezes entendida como inerente ao trabalho do agente penitenciário e em outras foi identificada como exclusivamente das mulheres encarceradas. Embora a partir de uma crítica incipiente, um terceiro aspecto foi apontado pela agente como determinante das possibilidades de ressocialização das presas: a questão social e o contexto socioeconômico de onde as mulheres são provenientes. Em-

Mailing address: Pontifícia Universidade Católica do Rio Grande do Sul, Ipiranga Avenue, 6681, Partenon, Porto Alegre, RS, Brazil 90.619-900. E-mail: mariana.barcinski@pucrs.br 
bora tal crítica não tenha sido aprofundada no discurso da participante, entendemos que o fracasso ou as dificuldades inerentes ao processo ressocializador deva também ser creditado a uma estrutura social que obstaculiza as possibilidades reais de reinserção social. Portanto, ressocializar seria simultaneamente o resultado de esforços pessoais (das presas e das agentes) e de uma configuração social mais justa e igualitária.

Palavras-chaves: Ressocialização, instituição prisional feminina, agentes penitenciárias.

\section{Significados de la Resocialización para las Agentes Penitenciarias en una Cárcel Femenina: Entre el Cuidado y el Control}

\section{Resumen}

El presente estudio objetivó investigar la percepción de una agente penitenciaria acerca de sus atribuciones, especialmente sobre su papel como coparticipé en procesos de resocialización de mujeres privadas de libertad. A través de la Análisis Critica del Discurso de una entrevista semiestructurada, se identifican significados contradictorios atribuidos por esta agente al proceso de resocialización. Al explicitar las particularidades de su día a día de trabajo, los sentidos de la resocialización y la responsabilidad fue por veces entendida como inherente al trabajo del agente penitenciario, en otras fue identificada como exclusivamente de las mujeres encarceladas. Mismo a partir de una critica incipiente, un tercer aspecto fue apuntado por la agente como determinante de las posibilidades de resocialización de las presas: la cuestión social y el contexto socioeconómico de donde las mujeres son provenientes. Mismo que tal critica no haya sido profundizado en el discurso de la participante, entendemos que el fracaso o las dificultades inherentes al proceso resocializador deba también ser acreditado a una estructura social que obstaculiza las posibilidades reales de reinserción social. Por lo tanto, resocializar seria simultáneamente el resultado de esfuerzos personales (de las presas y de las agentes) y de una configuración social mas justa e igualitaria.

Palabra clave: Resocialización, cárcel feminina, agentes penitenciarias.

In December 2013 our group started performing the interviews that compose part of the research field work titled "Ambiguities and contradictions on a correctional officer's practice of caring and watching: consequences to occupational health". This research consisted of a qualitative design study which aimed at investigating the meaning of the female officers' job inside prison units meant exclusively for women inmates in the state of Rio Grande do Sul, Brazil.

Besides the specific interest in their work and in the relationships established between these professionals inside prisons, the qualitative study interviews raised equal interest in the dynamics held in total institutions (Goffman, 1996) - its complete feature is perceived through the barriers imposed to the social relations with the outside world. As total institutions, a prison is configured as a place of residence and work of those who are imprisoned, kept apart from wider society for a considerable length of time, which leads the inmates to a shut life, intensely controlled and formally managed. The prison institution, as emphasized by Fonseca (2006), promotes not only the convicts' imprisonment, but also the guards', from the moment they are subjected to routine and standardization of the prison system.

The state implicitly delegates to correctional officers the task of selecting the appropriate conduct and corrective measures to be taken in prison, transferring the responsibility of inmates' punishment to these agents (Silva, 2009). To execute their functions, agents must apprehend the dynamics of living in the world of captivity and, at the same time, constantly affirm the hierarchy of relationships established with the individuals deprived of their freedom. 
On stigmas which highlight the identity of the correctional officer, Lourenço (2010) states that for society in general, these professionals are considered discreditable and potentially corruptible as a result of their proximity to delinquency, marginality and transgression. On the other hand, to prisoners in their daily lives, agents represent the institutional goals of surveillance and control; which forces the inmates to live in an unbalanced relationship of domination with the agents.

During the data collection of the aforementioned research, the interviews revealed the deep conflict that portrays the practices and, consequently, the identities of the penitentiary agents. Their speeches would express the inherent contradictions to this profession, whose practices are simultaneously supported by punitive and resocialising ideals. According to Nery (2012), it is expected from the agents that they punish and control as well as educate and resocialize prisoners. Among this confusion in the agents' assignments, prison ambiguities expressed in the mission to both punish and resocialize the persons deprived of freedom. Agents 'reports not only expressed the conflicting feelings regarding the prisoners with whom they kept daily contact, but also the obvious conflict arisen from the need to take at the same time the roles of controller and resocializator agent.

This article intends to investigate, from a case study, the perception of a female prison agent about her duties, especially on her role as a co-participant in rehabilitation processes of women deprived of liberty. Therefore, its main goal is to analyze the way this agent discursively builds the meaning of rehabilitation, understood as one of her duties in the prison system.

In order to deepen the meaning of this inherent conflict in the practices of correctional officers, the notion of rehabilitation and criminal treatment is historically outlined below so as to understand how prison takes to itself the corrective mission of social transgressors. This is about understanding how the individual conflict expressed by the agents has a historical trajectory which establishes the prison as a space of control and resocialization simultaneously.

\section{Prison History: Between Punishment and Penal Treatment}

According to Foucault (1975/2010), the legal system historically based its actions on a coercive method in the service of public defense and the correction of social norm transgressors. By the early eighteenth century, the correction of offenders was accomplished through physical punishment, materialized in the misery of the body. In order to provide a public model of suffering, the torture aimed at the reconstruction of the broken social order.

In the eighteenth and nineteenth centuries the spectacle of torture was replaced by disciplinary procedures that characterize the transition to a punitive model supposedly more humane. Therefore, violation of the body and its public exposure gave way to more covert forms of control of transgressions: isolation and deprivation of freedom imposed by the prison. Punishment no longer exerted directly on the physical body is intended to correct and socially reinsert. Violence, once exercised over the bodies, acts in a manner no less incisive, nullifying the desires and personal volition (Fonseca, 2006).

The history of prison, historically guided by the dual mission of punishing and correcting individuals, outlines a scenario in which conflicting speeches permeate the practices inside it. Substantiated in its mission of transforming individuals, prison, with its "prison machinery" (Foucault, 1975/2010, p. 208), operates from the logic of coercion and subordination.

According to Carvalho (2001, p. 111), in a historical view of sentences and their implementation, the Brazilian prison model "fuses the torture of the body and the training of the soul". Therefore, our prison reality bases the execution of the sentence on the punishment of the physical body and the disciplinary practices of control and regulation of individuals submitted to it.

The origin of the humanizing concern of penalties, embodied in the figure of Beccaria, precursor of criminals' human rights, dates back to the eighteenth century (Herreira, 1995). According to the author, the history witnesses a setback regarding this resocialising prison ideal, 
especially until 1945 , when criminal law was responsible for protecting the state from political dissidents. The criminal stiffness of the time, then, contrasts with the defense of human rights.

The movement of New Social Defense, inaugurated in the 50's, establishes resocialization as the main objective of the sentence. According to this movement, the objective of social reintegration of the offender, materialized from their treatment, should guide the prison reform. The penalty, understood as a form of punishment, is reframed as a form of treatment, aiming to socially adapt the criminal.

In Brazilian legislation, the Law of Criminal Executions (Law No 7.210, 1984), or simply "LEP", in its first article, lists as one of the goals of criminal execution "providing conditions for the harmonious social integration of the convicted and the inmate". The assistance to the prisoner concerning their health, legal, educational, social and religious needs are, according to the same law, the State's duty in its mission to provide the return of the convict to life in society.

Cervini (2002) states that between security and socialization, the modern prison system opted for socialization and social therapy. In this new conception of criminal policy, the idea of suffering and punishment was replaced by a more humane one based on the ideology of treatment, which aims at rehabilitating of the prisoner to return to society. Therefore, through more humanized interventions, the resocializating treatment seeks to recover the individual who committed any offence. Thus, the current prison system is replaced by the enacted mission of educating and correcting deviant subjects (Baratta, 1999).

The Brazilian prison system considers the rehabilitation of prisoners a form of readjusting them to social life (Santos \& Souza, 2013). Although LEP asserts the state's role in the treatment and social integration of convicts, there is (implicit in the concept of rehabilitation) the belief that it is up to the transgressor to make the changes - value and conduct changes - which will supposedly ensure their post incarceration reintegration into society. Thus, considering it an individual redemption movement, the process of rehabilitation would presuppose repentance for the crimes / offences committed as well as the genuine personal desire for transformation.

In a recovery model focused solely on the individual's imprisonment - and its consequences -, part of the responsibility of a successful treatment done by the prison is attributed to the prison officers in the penitentiary system: the technical staff and the correctional officers. After the sentence is imposed by the judge, these professionals are the ones who define the best strategies to educate, correct and reintroduce the subject into society (Wolff, 2005).

According to the Article 5 of LEP, when stepping into the prison system, "convicts will be classified according to their background and personality, to guide individualization of penal punishment by law enforcement". It is up to the system experts - service chiefs, psychiatrists, psychologists and social workers - the definition of the so-called penalty individualizing plan, which will provide the guidelines for the compliance of each individual sentence.

Therefore, the individualization of the process, which is conventionally called social reintroduction of prisoners, is personified in specific individuals, leaving the social character of the process and its chances of success untouched. The inmates and the system workers are the ones who build together individual plans aiming at social reintegration of former convicts. Thus, the satisfactory achievement of these plans, expressed in non-recurrence, depends on the willpower and the prisoner desire for change as well as the technical capacity of the system professionals.

Cervini (2002), however, emphasizes that rehabilitation is a process that should consider both the individual and the society in which they are inserted. The conception of social reintegration treatment focused exclusively on the figure of the transgressor individual reinforces the notion of crime and transgression as a result of an individual deviation. Through this perspective, some individuals would have natural predisposition to crime, either due to personal features - biological or psychological - or the impact of 
the surrounding environment. Strategies to reduce crime, consequently, would be directed to the individual, to correcting their behavior and making it adequate (Baratta, 1999).

As reported by Mello (2014), the intention to socially reintroduce the individual without critically evaluating the social environment in which one is planned to be incorporated means accepting the actual social order without questioning its structure and forms of relationship established therein. The author points out how social structures play a central role in both the processes of criminalization of social groups and the possibilities of social reinsertion of individuals after the completion of their sentences. It is in this sense that any attempt of social reintegration presupposes a simultaneous look at the individual who intends to see themselves (re)inserted into society, which, in turn, must be prepared to receive this individual, transforming itself in order to provide less unequal relations in its scope.

Therefore, the process of rehabilitation should not focus exclusively on the person of the convicts, but on the relationship they establish with society, so we can understand their deviant and criminal conduct. Keeping that in mind, Sá (2000, p. 21) suggests that the term "social reintegration" would be more appropriate since it recognizes that the convict comes from a context of marginalization and that incarceration represents the officialisation of the antagonistic and non-inclusive relationship established between this individual and the social sphere.

According to Santos and Souza (2013), the social reintegrating model that prisons propose is, in essence, contradictory. When entering the prison system, the detainees have the responsibility of (re)constructing their citizenship and dignity without the system's consideration in relation to the impossibilities of this construction in an environment completely deprived of freedom. There is a contradiction between the process of re-educating people for freedom in an environment deprived of freedom and socially stigmatized. In this sense, Azevedo, Silva and Barros (2012) argue that the prison is not a social reintegrating place, since it does not reeducate, include or humanize people. Thus, the prison fails to fulfill its central role: to reintegrate in order to provide conditions for the return to adequate social coexistence. It is expected that convicts go through a reform that makes them return to social life with new ideals after leaving prison.

Although arrests have historically been carried out intended to punish so as to achieve moral recovery for the detainees, Rosa (2014) confirms that this model does not meet the political and social needs of recovery of the prison population for their return to society. Keeping the subjects away from their environment without offering conditions regarding health, work or opportunities of building a new life project has resulted in obvious increase of institutional and social violence, which directly affects recidivism rates in crime and the consequent increase in the prison population.

Cervini (2002) points out that rehabilitation is possible only when the individual to be restituted to society and in charge of the rehabilitation accepts or shares the same understanding of the current social norm.

About the negative impacts of imprisonment, contrary to the promulgated ideal of social reintegrating prison, Wacquant (2004) points out that the prison experience serves to deepen the poverty framework and isolation that many individuals have experienced before prison. According to the author in relation to the French prison context, $60 \%$ of prisoners who leave prison are unemployed, in comparison to $50 \%$ who enter prison in the same situation.

\section{The Role of the Agent: Between Resocialising and Punishing}

One of the issues regarding the practice of correctional officers is the ambiguity of the function. The standardization of their functions through legislation and the practice of their daily work express contradictions. According to LEP, the agent must work for the rehabilitation of the inmates and prepare them for their return to society. Therefore, not only will the prison institution, by means of punishment and deprivation of liberty, punish the subject for the crime, but it in- 
tends to modify them using discipline as a mechanism. This prison double mission - punishing and educating - turns the relations established between prisoners and correctional officers contradictory and ambivalent because the agent is the one who offers support and assistance to the inmate in the same context where steadily encloses, represses and punishes them (Fonseca, 2006).

On the complementary Law No. 13.259, from October 20, 2009, which features the prison personnel in the state of Rio Grande do Sul, Brazil, the following assignments are listed as belonging to the position of prison guards: custody, escort, discipline and safety of prisoners; patrols in the prison wards, galleries, barracks, cells, courtyards and other premises; structural inspection of the wings, galleries, barracks, cells and other facilities of prisons; occurrence report to the competent authorities; control and daily conference of the prison population in all areas of the prison; supervision and inspection of the prison work and the conduct of prisoners; the acts and procedures of disciplinary infractions.

In the aforementioned duties, it is noted that the purpose of the agent's work reflects on the maintenance of order and security of penal institutions, having control, surveillance, custody, supervision and monitoring under their scope. While the control functions above are mentioned, in the constitution of complementary Law No. 13.259 there are elements that emphasize humanization and the reintegrating role of the prison guard. In this sense, they would be responsible for "watching, guiding and monitoring the criminal treatment actions in the aspects of preventive care and socialization for the prisoner" and "guiding and performing work ... to instruct the prisoners over hygiene habits, education and good manners, the awakening of the sense of responsibility, dedication to the fulfillment of family, professional and social duties".

Therefore, some confusion can be seen, which denotes the dual function of the prison and, consequently, the prison guard. This role ambiguity experienced by the agents, who have to both punish and resocialize, may be a propel- ling factor of difficulty when positioning the agent regarding their own practice and even the attitudes to be taken in front of the prisoners. The rehabilitating role becomes hard, since, according to Wacquant (2004), there is a challenge to resocialize from isolation, from the disruption of affective and social ties and punitive practices that revictimise prisoners constantly.

Returning to the interviews performed in this research, while the officers spoke about their roles in a female prison institution, they emphasized the resocialization of the inmates as the primary duty. However, their speeches attribute the responsibility for success in rehabilitation to different factors, perceiving this mission as the result of individual efforts (from prisoners who wish to resocialize), institutional efforts (from themselves as reintegrating agents), or even social efforts (a preparation from society to receive former inmates). In this sense, the meaning of rehabilitation acquires more individualized and more socially critical contours, resulting in conflicting speeches. The fact that these penitentiary agents work exclusively in female prisons endows the understanding of the resocialization process with peculiar characteristics, which are characterized by gender issues and their expressions in the singular context of a total institution.

The often assumed task of acting as the main motivators of moral recovery processes of the prisoners is built through speeches that emphasize the supposedly natural ability of women to do so. Colling (2004) states that women are stimulated to take care of children and do housework, with an interwoven and subordinate social role in care and support. Such hegemonic representation of the feminine establishes women as inherently more prepared for the care, protection and education of those around them, legitimizing these characteristics as essential to women. At the same time, the demand for punishment from women officers and the need for them to keep authority in front of the inmates must be highly stressful for these officers, because at this time, the agents resort to characteristics associated with men, such as assertiveness and aggressiveness (Barcinski, Alternbernd, \& Campani, 2013). 


\section{Method}

\section{Design}

This work is designed as a case study, a method that allows the achievement of a thorough description of the phenomenon researched in it, namely, the meanings assigned by a prison guard to the rehabilitation of women deprived of liberty. According to Stake (2000), the choice of this method is justified by the belief that the study of a particular case will help us in understanding a broader phenomenon, providing insights for future potential generalizations.

The interview discussed in this article is part of a set of 10 interviews conducted between December 2013 and January 2014 in the four exclusively female prisons of Rio Grande do Sul, Brazil. These interviews were part of a research that aimed at investigating the daily work of prison officers, with particular focus on aspects of occupational health of this population.

The choice to analyze this one interview in particular is due to, firstly, our believing that its content reflects, in many ways, the dilemmas and conflicts theorized about their professional duties. In addition, the interviewee presented a critical position in relation to her activities particularly, and to the role of prison staff in general. In this regard, the dilemmas and ambiguities discussed theoretically were expressed in various ways in the interviewee's discourse. It is noteworthy that this survey strictly complied with all ethical procedures informed by Resolution 466/12 of the National Health Council and was approved by the Ethics Committee of the higher education institution to which the researchers are related.

\section{Participant and Instrument}

The interviewed prison guard was 34 years old and performed activities that required direct contact with the prisoners daily. At the time of the interview, Adriana (fictitious name) had been working as a prison guard for only two years, which in part might justify the critical position that she presented on the practice of agents in that very institution. Besides that, and in contrast to most women acting as agents, she had a degree in Pedagogy. At the time she took the public contest for the job, it was not a mandatory requirement for the prison officer position yet. Adriana worked in a maximum security prison which had been recently opened.

The semi-structured interview included a script of questions conducted in a flexible and open manner, the objective of which being the stories to be told with maximum comprehensiveness and minimal embarrassment. Such questions were about the agent's personal and professional background, specifically focused on the dilemmas experienced in her daily professional practice. This interview lasted for about an hour.

The purpose of the interview was to provide agents the opportunity to report, from their individual experiences, any eventual difficulties which arise from the exercise of their profession. In a way, from the conflicts described in their own description of their duties, it was hoped that her speech was going to be marked by ambiguities and contradictions, especially while speaking about her daily work. Thus, we sought to provide a space so that Adriana could tell us how she acted, the feelings that emerged from this action, the contradictions she experienced, etc., taking into account the role assigned to her in the prison context, ranging from punishment to rehabilitation, as previously discussed. The interview was recorded in audio, with the consent of the participant, and transcribed entirely for the discourse analysis proposed in this research.

\section{Data Analysis}

For data analysis, the Critical Discourse Analysis was used as an investigating tool, which aims at understanding the relation between discourse and power (Van Dijk, 2008). In summary, this method of analysis seeks to understand the discursive practices as historically situated modes of action. Through this perspective, the discourse is shaped by the social structure, and vice-versa (Resende \& Ramalho, 2006). According to Fairclough (2008), the speech should be understood as a form of social practice, and not as a purely individual production, showing the dialectical relationship between discourse and social structure. It is in this sense that we 
must understand that the discourse produced by a prison guard in the interview situation, for example, reflects the institutional and social context occupied by her and in which she performs her activities.

\section{Results and Discussion}

The focus of the participant discourse analysis reflects the ways she signifies the rehabilitation process of the prisoners. It was evident throughout the interview that the discourse on rehabilitation - about its possibilities, motivations, difficulties and obstacles - was confused with the description of Adriana's own labor assignments themselves. In other words, we realized that the task of rehabilitation was intrinsically related to her understanding of her own everyday functions as an agent. Resocialising the inmates, or helping them in their personal processes towards rehabilitation, was described by the interviewee as a professional obligation. Therefore, excerpts from the speeches analyzed were about how Adriana understands her responsibilities, stating rehabilitation as one of her main duties.

The results also point to the meanings that the interviewee attributed to rehabilitation and to whom she gave responsibility for leading the rehabilitation process. This accountability at times was associated with the prison guard function itself; at others, it was seen as something that depended on the will to change of those women deprived of liberty. Social issues, such as questioning the living conditions inside and outside the prison, were also listed as constituent elements of the possibilities or impossibilities of social reintegration.

The excerpts analyzed even point to the peculiarity of the position taken by the respondent as being a female penitentiary agent. Hereupon, the contradictions, ambiguities and dilemmas expressed may result mostly from the fact that Adriana is a woman caring for, watching and controlling other women in her daily work. Therefore, gender issues permeate these analyses by permeating the conception of this highly complex job.
Regarding relational aspects involved in the daily practice of the prison guard position, the respondent emphasized the need for agents to delimit an emotional detachment from the inmates, not to establish any emotional bond with them. Sustained by this belief, Adriana characterized her work practice from the following perspective - an undifferentiated treatment granted to prisoners guided by the recognition of equality between them:

... I treat all of them as people, and none is different to me, so when the ones who work - who leave without handcuffs ... I don't accept when they come to appointments without handcuffs. If I am the one to go there, I do handcuff them, because she is an inmate just like the others, to me no one has any privilege here. I always say to them that they have the shorts they got, right? And there are some that cut them or fold them, I always say, "you are no different from anyone here, so you have to wear those shorts just like the others do, to me there is no difference".

In the excerpt above, in which Adriana emphasizes the supposed equality treatment granted to the inmates - whether they are working inside the prison or not - the severity of such treatment is evident. In addition to the differentiation in the treatment given to the prisoners, Adriana emphasizes the humane feature with which she supposedly endows her practice as an agent: "to me they are people, I don't treat them as inmates, because I think they have already been convicted. Here inside, to me, I work as if I had been working out there, you know?".

If, on one hand, Adriana sees herself as one that conducts her work in a more humane way by treating women deprived of freedom "as people" and not from the stigma usually associated to them, on the other hand she exposes the con-duction of a coercive and prohibitive practice. This is noticeable both in the obligatoriness - imposed by Adriana herself - that all prisoners be handcuffed when they go to appointments, as well as in the impediment to their customizing their uniforms. This last-mentioned aspect grants the women some will regarding their personal 
presentation and it represents, to some extent, a reaction to the depersonalization and standardization imposed by the prison (Cunha, 1994).

The expressed ambiguity between this more humane and a more controlling view directed to women deprived of liberty illustrates, in part, the dilemma inherent to prison itself in its double mission of rehabilitating and punishing, caring for and controlling those submitted to its rules and daily dynamics (Barcinski et al., 2013).

Throughout the interview Adriana sought to differentiate her practice from that performed by other prison officers. In the excerpt below, the humanized character of her work was justified not from an understanding that this view must be present in the everyday practice of the penitentiary agent, but as a result of a personal attribute. This attribute is emphasized during the interview as a result of Adriana's study in Pedagogy: "I think I have a different look due to that, maybe if it were another colleague, they would see it differently. I can't see them as anything other than people".

The resource to individualization of treatment which is provided places at the same time the participant as fundamentally different (and better) compared to the majority of agents and subtly reassures the expectations concerning the work of these professionals. In other words, to emphasize her humane treatment, Adriana reinforces the socially built image of agents as aggressive, punitive and coercive (Lourenço, 2010).

In many moments during the interview, Adriana expressed the expectation of reciprocity which comes from the inmates, with regard to the respect and care provided by her. At times, when describing her relationship she establishes with the inmates on a daily basis, the officer ignored the natural hierarchy status between them, not acknowledging herself as the one who controls and watches. Therefore, her frustrations showed lack of feedback from the imprisoned, as if the relationship established between them were similar to that between co-workers. And it is in this sense, from a relation made by an artificial symmetry, that Adriana expects prisoners' recognition for her humanizing efforts:
It's that feedback, they don't understand, we always go like, they aren't here because we want them to, right? It was not because of us that they got in here, and sometimes they ... they hate anyone [any agent], no matter who it is, right?

The expectation of reciprocity demonstrates the desire for emotional complicity. Despite sustaining the need for emotional detachment, the interviewee seemed to resent when this distance showed by the inmates make them come to "not liking the agents anymore". Adriana's speech expressed the desire to be well liked and recognized by the women deprived of freedom, especially for the humane way in which she treats them and how she performs her work in the institution.

While things are going their way, everything is okay; but suddenly if there is something that they cannot do, and we say no, then they no longer like most of us, what can't be done just can't be done, but they won't accept it.

The expectation of reciprocity in the affection dispensed to the inmates contrasts with the emotional detachment, previously described by Adriana as a key feature in the work of an agent. The ambiguity between the establishment of mutual relations of affection and the need for emotional detachment points to the peculiarities of the work done by women agents. In addition to the expected control and surveillance to be exercised on the prisoners, Adriana refers to care as part of their occupation. About the feminization of the work, Marcondes (2013) points out that care, as a social practice that is anchored in the sexual division of labor, presupposes a relationship of interdependence between those who care and those who are taken care of. In this sense, while meeting the inmates' needs, the interviewee expects the acknowledgement of this care through the establishment of understanding and reciprocity relations.

In other excerpts, when talking about her daily duties, Adriana coated her practice with a potentially nobler sense, that would not, in theory, belong to the position of prison guard. The agent reported taking on psychologist, 
mother and physician roles at times, situating them in childlike and intellectually inferior positions.

Because with a woman you have to go there, you are a mother, a psychologist, a doctor, all in one, it is a big child that's there, that you have to be patient with, you have to explain, you have to try to make her understand that today there will not be the treatment she wants, she will have to wait a little bit, right?

Below, the interviewee reiterates her caring role towards the inmates resorting once again to their infantilization:

I think that in our work, in short, we are the nanny of the prisoners, we have to do everything and take care of them, and it is not far from that, summarizing that's our job, we can not fail to provide care, take them to the doctor is taking care of them, right?

The previous sections reflect an important feature of the prison culture, namely the infantilization of captives (Goffman, 1996). In her speech, Adriana recurrently places the agents as those who need to learn to deal with childish, inappropriate and uncivilized behaviors. Such as nannies and/or mothers, agents must assume the role of educating and giving limits to the inmates. In this sense, Adriana describes her tasks as based on the skills socially expected from mothers, for instance flexibility, assertiveness, patience and care.

Care, once again, emerges as a central element in the description of Adriana's work activities. From a gender perspective, we can understand how the care of people - whether on the domestic or work sphere - is socially constructed as a defining element of the feminine. Yannoulas (2011) emphasizes that meeting the needs of others presupposes the presence of supposedly feminine traits such as docility and patience. As sweet, patient, understanding and empathetic, Adriana is able to act simultaneously as an agent, as a mother, as a psychologist and as a friend of the inmates.

Alongside the civilizing and corrective functions within the prison, rehabilitation was identified by Adriana as one of the duties - if not the main - of the prison guard's work. At times, the interviewee attributed the responsibility for conducting the resocialising process as inherent to her function as an agent, although she has simultaneously marked the individualizing character of this process: "This is something that doesn't depend only on us [the rehabilitation of prisoners], it depends more on them, right?"

It is worth noting that the expectation of Adriana on the resocialization of inmates is linked to the existence of a desire for change on their part, without which the efforts of agents will not be effective. So, even if they are placed in a childish position and without autonomy within the prison, the prisoners are still responsible for the possibilities of change. In the excerpt below, Adriana returns to the idea that it is up to them to follow the agents' advice, the appropriate way of resuming their lives outside prison.

There are the ones who get in for the first time and they are soon freed, and we always say to them "Don't you come back again, just don't". There was one who once said that she had a child, such a young and beautiful girl, then I said "So, now you're getting out, go and take care of your daughter, right? Take over your life, have a different life". Then she turned to me and said "No, it is not worth it to keep on cleaning the homes of others for a salary because I get around 300, 400 bucks per hour delivering drugs", so she preferred this life, and then I said "So what? Is it worth it in the end?"

In the previous section, the agent reassures the need for the inmates to hear the agents' advice, built as the voice of wisdom and rationality in their orientation for them. Adriana attributes great power to such advice in the rehabilitation process. Therefore, according to Adriana's speech, rehabilitation could be materialized from what agents state to the inmates as being right to them. Considering that, Adriana's speech emphasizes again the personal responsibility of inmates for their rehabilitation process, while keeping them in a childish or morally inferior role, as ones who need the advice from people able to grant it. In providing her reintegrating advice, the interviewee stands also as the guard- 
ian of their morality, function socially assigned to mothers in relation to their offspring (Lewis, 2002).

During the interview Adriana references to the presence of a third aspect which is determinant in the prisoner's' resocialization possibilities: the social issue and the socioeconomic context in which women deprived of freedom are coming from. In a way, the agent recognizes the precariousness of society in granting the basic rights to these women, which contributes to prison recidivism. Although her social criticism has not been forceful or deeply founded, it arises incipiently in the following section.

I think they have to be treated well, so as to see the difference in how they are treated out there ... Sometimes people do not appreciate, do not treat them well and they end up fighting back, you know? . . . Here they have more rights than us when out there, so they might find themselves even more valued here, right?

By arguing that the resocializating process encounters obstacles in a social structure marked by the absence of minimum survival conditions, Adriana says that women prisoners would most likely be valued and have more rights inside the prison.

The above statement shows a social criticism that complexities the understanding of this rehabilitating process. In this sense, Adriana credits its failures or difficulties not only to the unwillingness of the prisoners or their personal features, but also refers to a social structure that obstructs the real possibilities of social reinsertion. So, resocialising would be, in the speech of the interviewee, simultaneously the result of personal efforts (from inmates and agents) and a fairer and more egalitarian social setting.

\section{Final Considerations}

The aim of this study was to analyze the way a prison guard discursively constructed the meaning of rehabilitation, understood as one of her duties in the prison system. The participant's speech which we analyzed must be understood as a product of interconnected issues inherent to the prison institution in its mission of caring for and monitoring as well as to her personal and professional life. Adriana's speech simultaneously reflects the peculiarities of her choices and beliefs, as well as social expectations over the role of prison officers. These expectations place the women agents differently than men agents, with regard to the quality of the interactions established with the persons deprived of liberty. If on the one hand it is expected from men that they take exclusively control functions, on the other hand women agents also incorporate care as a defining element of their practices.

When explaining the specifics of her dayto-day work, the sense of rehabilitation the and responsibility before the resocializating process of the prisoners are reflected in the speech of the interviewee. This responsibility was understood recurrently as inherent to the work of prison guard. In other speech excerpts from the agent, the chances of rehabilitation were identified as conditioned, almost exclusively, to the will of the incarcerated. In both cases, the importance of the inmates following the advice given by the agents was identified as a relevant factor for the non-recurrence. Finally, the agent makes a discrete social critique by questioning the possibilities of resocialization of imprisoned women in an unjust social structure and unprepared to respond to the prisoners and agents in their joint efforts to promote rehabilitating processes.

In addition to seeking to determine, through the perspective of a prison guard, the responsibility for the rehabilitation process of former convicts, it is considered important to problematize the concept of rehabilitation. Considering the male and female prison population in Brazil, it is possible to identify, in a general way, a young population, with low education and from lower social classes. In this regard, segregation and isolation provided by the prison experience only stoked the condition of marginalization that such people lived before incarceration.

From this scenario, the meaning of these attempts at "resocialising" those who have never been equally socially inserted is questioned. More urgent than the search for resocialization, usually understood as the result of personal 
efforts from redeeming convicts, might be the struggle for integration and non-exclusion of people who still live on the margins of society. If we understand the phenomenon of imprisonment a result of a more complex movement of social and economic segregation, inevitably we also have to expand our understanding of the factors that contribute to the real possibilities of rehabilitation.

\section{References}

Azevedo, R. O., Silva, M. M., \& Barros, D. M. V. (2012). O papel do agente penitenciário no processo de humanização no presídio do Distrito Federal - Colméia. Projeção, Direito e Sociedade, 3(1), 252-266.

Baratta, A. (1999). Criminologia crítica ao Direito Penal Brasileiro (2 ${ }^{\text {nd }}$ ed.). Rio de Janeiro, RJ: Freitas Bastos.

Barcinski, M., Alternbernd, B., \& Campani, C. (2013). Entre vigiar e punir: Ambiguidades e contradições do agente penitenciário. Ciência \& Saúde Coletiva, 19(7), 2245-2254.

Carvalho, S. (2001). Práticas inquisitivas na execução penal (ou, o aprisionamento do juiz pelos laudos criminológicos: uma abordagem garantista). Doutrina, 1(11), 111-132.

Cervini, R. (2002). Os processos de descriminalização. São Paulo, SP: Revistas dos Tribunais.

Colling, A. M. (2004). O corpo que os gregos inventaram. In M. N. Strey \& S. T. L. Cabeda (Eds.), Corpos e subjetividades em exercício interdisciplinar (pp. 49-64). Porto Alegre, RS: Editora Universitária da Pontifícia Universidade Católica do Rio Grande do Sul.

Complementary Law No. 13.259. (2009). Retrieved from http://www.al.rs.gov.br/ legiscomp/arquivo.asp? Rotulo $=$ Lei $\% 20$ Complementar\% 20 n \% C $2 \%$ B A \% 20 $13259 \&$ idNorma $=990 \&$ tipo $=$ pdf

Cunha, M. I. P. (1994). Malhas que a reclusão tece. Questões de identidade numa prisão feminina. Lisboa: Gabinete de Estudos Jurídico-Sociais.

Fairclough, N. (2008). Discurso e mudança social. Brasília, DF: Universidade de Brasília.

Fonseca, K. P. (2006). Re(Pensando) o crime como uma relação de antagonismo entre seus autores e a sociedade. Psicologia: Ciência e Profissão, 26(4), 532-547.

Foucault, M. (2010). Vigiar e punir: O nascimento da prisão. Petrópolis, RJ: Vozes. (Original work published 1975)

Goffman, E. (1996). Manicômios, prisões e conventos. São Paulo, SP: Perspectiva.

Herreira, A. S. (1995). Nova defesa social. Akrópolis, 3(12), 20-25.

Law No. 7.210. (1984). Law of Criminal Executions. Retrieved from: http:/www.planalto.gov.br/ ccivil 03/leis/17210.htm

Lewis, S. (2002). Concepts of motherhood. In H. Klee, M. Jackson, \& S. Lewis (Eds.), Drug misuse and motherhood (pp. 32-44). London: Routledge.

Lourenço, L. C. (2010). Batendo a tranca: Impactos do encarceramento em agentes penitenciários da Região Metropolitana de Belo Horizonte. Dilemas: Revista de Estudos de Conflito e Controle Social, 3(10), 11-31.

Marcondes, M. M. (2013). O cuidado na perspectiva da divisão sexual do trabalho: Contribuições para os estudos sobre a feminização do mundo do trabalho. In S. C. Yannoulas (Ed.), Trabalhadoras: Análise da feminilização das profissões e ocupações (pp. 251-279). Brasília, DF: Editorial Abaré.

Mello, D. C. D. (2014). A prisão feminina: Gravidez e maternidade: Um estudo da realidade em Porto Alegre-RS/Brasil e Lisboa/Portugal (Doctoral dissertation, Ciências Criminais, Pontifícia Universidade do Rio Grande do Sul, Porto Alegre, RS, Brazil).

Nery, T. R. A. (2012). Da ética à poética do ser servidor penitenciário. Porto Alegre, RS: Companhia Rio-Grandense de Artes Gráficas.

Resende, V. M., \& Ramalho, V. (2006). Análise de discurso crítica. São Paulo, SP: Contexto.

Rosa, S. M. (2014). Instituições prisionais: Atenção psicossocial, saúde mental e reinserção social. Fragmentos de Cultura, 24(1), 125-138.

SÁ, A. A. (2000). Algumas ponderações acerca da reintegração social dos condenados à pena preventiva de liberdade. Esmape, 5(11), 25-70.

Santos, T. S., \& Souza, S. B. (2013). Da condição de "ressocialização" dos egressos do sistema prisional. Café com Sociologia, 2(3), 25-35. 
Between Care and Control.

Silva, R. M. (2009). O papel do agente penitenciário na prevenção da violência. Retrieved from http://agepensczs.blogspot.com.br/2011/04/opapel-do-agente-penitenciario-na.html

Stake, R. E. (2000). Case studies. In N. K. Denzin \& Y. S. Lincoln (Eds.), Handbook of qualitative research (pp. 435-454). London: Sage.

Van Dijk, T. A. (2008). Discurso e poder. São Paulo, SP: Contexto.

Wacquant, L. (2004). A aberração carcerária à moda francesa. Revista de Ciências Sociais, 47(2), 215-232
Wolff, M. P. (2005). Antologia de vidas e histórias na prisão: Emergência e injunção de controle social. Rio de Janeiro, RJ: Lumen Juris.

Yannoulas, S. (2011). Feminização ou feminilização? Apontamentos em torno de uma categoria. Temporalis, 11(22), 271-292.

Recebido: 09/02/2016

$1^{a}$ revisão: $24 / 06 / 2016$

Aceite final: 05/07/2016 